\title{
Predictors of Short-Term Mortality in Hemodialysis Patients
}

\author{
Md. Mamunur Rashid ${ }^{1 *}$, Pradip Kumar Dutta ${ }^{2}$, Md. Nurul Huda ${ }^{3}$, Biplob Kumar Barua ${ }^{4}$, Dr. Mohammad Abdul Kader ${ }^{5}$
}

${ }^{1} \mathrm{MD}$ (Nephrology), Registrar, Nephrology, Evercare Hospital, Dhaka, Bangladesh

${ }^{2}$ Professor and Ex Head, Department of Nephrology, Chittagong Medical College Hospital, Chittagong, Bangladesh

${ }^{3}$ Professor, Head of the Department, Chittagong Medical College Hospital, Chittagong, Bangladesh

${ }^{4}$ Registrar of Nephrology, Chittagong Medical College Hospital, Chittagong, Bangladesh

${ }^{5}$ Assistant Registrar of Nephrology, Chittagong Medical College Hospital, Chittagong, Bangladesh

DOI: $10.36347 /$ sjams.2021.v09i02.009

| Received: 02.02.2021 | Accepted: 15.02.2021 | Published: 17.02.2021

*Corresponding author: Md. Mamunur Rashid

\section{Abstract}

Original Research Article

Objectives: In this study our main aim is to predict of short-time mortality in Hemodialysis patients. Methods: A prospective observational study was designed in 160 patients who were on maintenance hemodialysis twice and thrice weekly in different dialysis centers, Chittagong. At baseline information were collected \& patients were followed up until their death or upto 1 year. Results: Of 160 patients studied mean age was $50.11 \pm 13.21$ years, $66.25 \%$ were male, $35.00 \%$ were diabetic. Temporary dialysis catheters were the most common initial vascular access. The prevalence of positive hepatitis B virus surface antigen \& anti hepatitis C virus surface antibody were $15.625 \%$ \& $15.00 \%$ respectively. 38 patients died \& mortality rate was $23.75 \%$. Sepsis \& IHD were the most common causes of death. DM, low serum albumin \& high serum phosphorus were independent predictors of mortality. Conclusion: From our study we can say that, our findings indicated that mortality in patients on maintenance hemodialysis was disproportionately high. The most common causes of death were sepsis and IHD. Diabetes mellitus, low serum albumin and high serum phosphorus were found to be independent predictors of mortality. Higher serum albumin $\&$ low serum phosphorus level conferred a survival advantage.

Keywords: Twice weekly hemodialysis, thrice weekly hemodialysis, mortality.

Copyright $\left({ }^{\circ} 2021\right.$ The Author(s): This is an open-access article distributed under the terms of the Creative Commons Attribution 4.0 International License (CC BY-NC 4.0) which permits unrestricted use, distribution, and reproduction in any medium for non-commercial use provided the original author and source are credited.

\section{INTRODUCTION}

The definition of CKD is based on the presence of kidney damage (i.e., albuminuria) or decreased kidney function (i.e., glomerular filtration rate $<60 \mathrm{ml} / \mathrm{min} / 1.73 \mathrm{~m}^{2}$ ) for 3 months or more. The term "end-stage renal disease" (ESRD) generally refers to CKD treated with either dialysis or transplantation. There are approximately two million patients worldwide who regularly receive renal replacement therapy (RRT) in the form of dialysis. Of them, more than $80 \%$ are on hemodialysis (HD) and $15 \%$ are on peritoneal dialysis (PD), mostly from developed nations. Data from hospital, urban and underprivileged population based studies suggest that there is a CKD prevalence of 16-18\% in Bangladesh [1-3].

Data from hospital based studies and dialysis units suggest that chronic glumerulorephritis (proteinuria and bilaterally small kidneys) and interstitial nephropathy comprise $37 \%$ of causes of ESRD. Diabetic nephropathy constitutes $33 \%$ and hypertension $16 \%$. Prevalence of non dialysis ESRD is unknown. Data suggest that it could be 200-250 patients per million populations per year [4].

There are limited data regarding hemodialysis practice patterns from Bangladesh. We did this study to document the clinical profile of patients on maintenance hemodialysis (MHD) with special emphasis on various aspects of chronic kidney disease (CKD) stage 5D, such as anemia, mineral bone disease, vaccination, hypertension and cost of therapy in various dialysis units of Chittagong.

Mortality rates among hemodialysis (HD) patients exceed $20 \%$ per year [5]. Observational studies among prevalent HD patients have identified patient characteristics that are associated with greater mortality risk, including white race, older age, low serum albumin levels, low and elevated serum phosphorus levels, anemia, and cardiovascular disease [11-21]. Studies also have supported the importance of early nephrology referral in the pre-dialysis period for reducing mortality after HD initiation [6-17]. Data from the 2004 Annual Dialysis Report [10] indicate higher mortality rates for 
Mamunur Rashid et al; Sch J App Med Sci, Feb, 2021; 9(2): 217-222

patients who have received $\mathrm{HD}$ for $>5$ years as compared with $<2$ years, suggesting that length of time on HD modifies mortality risk. Most patients begin HD with several co-morbid conditions that may worsen or develop additional co-morbidities with continued dialysis.

\section{OBJECTIVE}

\section{General Objective}

- To determine predictor of short-time mortality in Hemodialysis patients

\section{Specific Objective}

- To find out demographic and socioeconomic profiles of ESRD patients.

- To assess biochemical parameters among patients on MHD.

- To determine associated factors (Vaccination, Vascular access, frequency of dialysis) related to dialysis practice.

\section{Methodology}

Type of study: Observational prospective study.

Place of study: Different dialysis centers, Chittagong.

Study period: 1 Year from approval of protocol by the ethical committee.

\section{Study population: Patients of ESRD on MHD.}

Study sample: MHD Patients in different dialysis centers of Chittagong.

Sampling technique: Convenience sampling.

\section{Procedure of Study}

This observational study was conducted at different dialysis centers in Chittagong district. Sample was collected by convenience sampling. Patients aged under 18 years, acute kidney injury (AKI) getting hemodialysis, pregnant women, those who dropped out or who switched over to other forms of renal replacement therapy like continuous ambulatory peritoneal dialysis (CAPD) and renal transplantation after inclusion into the study and patients who did not provide written consent to participate in this study were excluded. Selected patients with ESRD on maintenance hemodialysis were enrolled prospectively within 1 month and followed up over a period of 1 year. The study was started after approval by the institutional ethical committee and an informed consent was obtained from all the patients. Both the patient and his/her relatives were subsequently interviewed and data was collected into standard data collection form.

Data collection Methods: All data from interview, physical examination, laboratory parameter were collected in clinical record form.

\section{Data Processing and Analysis}

Mean \pm standard deviation (SD) and percentages were used for summarizing the data. Continuous variables were studied using the Student's ttest (two tailed, independent). Categorical variables were analyzed using the Chi-square and $2 \times 2,2 \times 4$ Fisher's exact tests. The primary endpoint of the analysis was death. Patients were followed-up and censored at the time of death or at the end of 1-year study period. Multivariate logistic regression analysis was performed to identify independent predictors of mortality. The confidence interval (CI) $95 \%$ and a P < 0.05 was used for statistical significance. All statistical analyses were performed with SPSS version 20.

\section{RESULT}

Table-1: Distribution of the socio-demographic characteristics of study population in alive and dead groups $(\mathbf{n}=160)$

\begin{tabular}{|c|c|c|c|c|c|c|}
\hline \multirow{2}{*}{ Feature } & \multicolumn{2}{|l|}{ Alive } & \multicolumn{2}{|l|}{ Dead } & \multicolumn{2}{|l|}{ Total } \\
\hline & Frequency & Percentage & Frequency & Percentage & Frequency & Percentage \\
\hline \multicolumn{7}{|l|}{ Age: } \\
\hline$<30$ years & 14 & 11.48 & 3 & 7.89 & 17 & 10.63 \\
\hline $30-45$ years & 31 & 25.41 & 8 & 21.05 & 39 & 24.38 \\
\hline 46-60 years & 53 & 43.44 & 15 & 39.47 & 68 & 42.50 \\
\hline$>60$ years & 24 & 19.67 & 12 & 31.58 & 36 & 22.50 \\
\hline \multicolumn{7}{|l|}{ Sex: } \\
\hline Male & 78 & 63.93 & 28 & 73.68 & 106 & 66.25 \\
\hline Female & 44 & 36.07 & 10 & 26.32 & 54 & 33.75 \\
\hline \multicolumn{7}{|c|}{ Economic dependency: } \\
\hline Independent & 29 & 23.77 & 14 & 36.84 & 43 & 26.87 \\
\hline Dependant & 93 & 76.23 & 24 & 63.16 & 117 & 73.13 \\
\hline \multicolumn{7}{|l|}{ SES: } \\
\hline Lower & 10 & 8.20 & 3 & 7.89 & 13 & 8.13 \\
\hline Lower middle & 42 & 34.43 & 7 & 18.42 & 49 & 30.63 \\
\hline Upper middle & 42 & 34.43 & 17 & 44.74 & 59 & 36.88 \\
\hline Upper & 28 & 22.95 & 11 & 28.95 & 39 & 24.38 \\
\hline
\end{tabular}


Mamunur Rashid et al; Sch J App Med Sci, Feb, 2021; 9(2): 217-222

\begin{tabular}{|c|c|c|c|c|c|c|}
\hline \multicolumn{7}{|l|}{ Locality: } \\
\hline Rural & 47 & 38.52 & 20 & 52.63 & 67 & 41.88 \\
\hline Urban & 75 & 61.48 & 18 & 47.37 & 93 & 58.13 \\
\hline \multicolumn{7}{|l|}{ Vaccination: (HBV) } \\
\hline Vaccinated & 79 & 64.75 & 15 & 39.47 & 94 & 58.75 \\
\hline Not vaccinated & 43 & 35.25 & 23 & 60.53 & 66 & 41.25 \\
\hline \multicolumn{7}{|l|}{ BMI: $\left(\mathrm{kg} / \mathrm{m}^{2}\right)$} \\
\hline$<18.5$ & 3 & 2.46 & 7 & 18.42 & 10 & 6.33 \\
\hline $18.5-24.9$ & 82 & 67.21 & 23 & 60.53 & 105 & 66.46 \\
\hline $25.0-29.9$ & 27 & 22.13 & 6 & 15.79 & 33 & 20.89 \\
\hline$>=30.0$ & 10 & 8.20 & 2 & 5.26 & 12 & 6.33 \\
\hline \multicolumn{7}{|c|}{ 8. Correction of anaemia } \\
\hline i. Erythropoietin & 33 & 27.05 & 7 & 18.42 & 40 & 25 \\
\hline ii. Blood transfusion & 77 & 63.12 & 29 & 76.32 & 106 & 66.25 \\
\hline iii. Both & 12 & 9.83 & 2 & 5.26 & 14 & 8.75 \\
\hline
\end{tabular}

Table-1 shows distribution of the sociodemographic characteristics of study population in alive and dead groups. 183 patients were recruited, 23 dropped out and 160 patients were included in the study.

Table-2: Comparison of co-morbidities between alive and dead population $(n=160)$

\begin{tabular}{|l|l|l|l|l|l|l|l|}
\hline \multirow{2}{*}{ Variables } & Alive & Dead & Total & p value \\
\cline { 2 - 8 } & Frequency & Percentage & Frequency & Percentage & Frequency & Percentage & \\
\hline DM & 50 & 40.98 & 24 & 63.16 & 74 & 46.25 & $0.017^{*}$ \\
\hline HTN & 111 & 90.98 & 37 & 97.37 & 148 & 92.50 & 0.192 \\
\hline IHD & 44 & 36.07 & 22 & 57.89 & 66 & 41.25 & $0.017^{*}$ \\
\hline HBV & 19 & 15.57 & 06 & 15.79 & 25 & 15.625 & 0.974 \\
\hline HCV & 21 & 17.21 & 03 & 7.89 & 24 & 15.00 & 0.160 \\
\hline
\end{tabular}

$\mathrm{p}$ values calculated by chi square and Fisher's exact test

DM=Diabetes mellitus; HTN=Hypertension; IHD=Ischaemic heart disease; HBV=Hepatitis B virus infection; $\mathrm{HCV}=$ Hepatitis $\mathrm{C}$ virus Infection

Table-2 shows that more than one third (40.98) patients had DM in alive, 24(63.16\%) in dead and 74(46.25\%) in total. (90.98). Majority $(90.98 \%)$ patients had HTN in alive, 37(97.37\%) in dead and 148(92.50\%) in total. More than one third (36.07\%) patients had IHD in alive, $22(57.89 \%)$ in dead and $66(41.25 \%)$ in total,
19(15.57\%) patients had HBV in alive, 6(15.79\%) in dead and $25(15.625 \%)$ in total, 21(17.21\%) patients had $\mathrm{HCV}$ in alive, $3(7.89 \%)$ in dead and 24(15.00\%) in total. The difference of DM and IHD were statistically significant $(\mathrm{p}<0.05)$ between two groups.

Table-3: Comparing Investigation profile in relation to patient outcome $(n=160)$

\begin{tabular}{|l|l|l|l|l|l|}
\hline \multirow{2}{*}{ Variables } & Alive & \multicolumn{3}{|l|}{ Dead } & p value \\
\cline { 2 - 5 } & Mean & $\mathbf{\pm S D}$ & Mean & $\mathbf{\pm S D}$ & \\
\hline Hemoglobin & 9.56 & \pm 1.09 & 9.03 & \pm 1.22 & $0.012^{*}$ \\
\hline Serum Ca++ & 9.32 & \pm 0.82 & 9.71 & \pm 1.05 & $0.017^{*}$ \\
\hline Serum phosphorus & 5.05 & \pm 1.56 & 6.50 & \pm 1.70 & $0.000^{*}$ \\
\hline Serum albumin & 3.56 & \pm 0.41 & 3.05 & \pm 0.03 & $0.000^{*}$ \\
\hline Serum Na+ & 140.87 & \pm 37.77 & 138.61 & \pm 2.67 & 0.713 \\
\hline Serum K+ & 4.75 & \pm 1.06 & 4.89 & \pm 0.69 & 0.464 \\
\hline
\end{tabular}

$\mathrm{p}$ values calculated by t-test

Table-3 shows the mean hemoglobin was $9.56 \pm 1.09$ in alive and $9.03 \pm 1.22$ in dead. The mean serum $\mathrm{Ca}++$ was $9.32 \pm 0.82$ in alive and $9.71 \pm 1.05$ in dead. The mean serum phosphorus was $5.05 \pm 1.56$ in alive and $6.50 \pm 1.70$ in dead. The mean serum albumin was $3.56 \pm 0.41$ in alive and $3.05 \pm 0.03$ in dead. The difference of hemoglobin, serum $\mathrm{Ca}++$, serum phosphorus and serum albumin were statistically significant $(\mathrm{p}<0.05)$ between two groups. 
Mamunur Rashid et al; Sch J App Med Sci, Feb, 2021; 9(2): 217-222

Table-4: Binary logistic regression analysis to identify predictors of mortality

\begin{tabular}{|l|l|l|l|l|l|l|}
\hline Variables & B & S.E. & \multirow{2}{*}{ P value } & OR & \multicolumn{2}{|l|}{ 95\% C.I.for EXP(B) } \\
\cline { 6 - 7 } & & & & & Lower & Upper \\
\hline Serum albumin & 1.523 & 0.419 & $0.001^{\mathrm{s}}$ & 4.584 & 2.015 & 10.430 \\
\hline DM & 1.158 & 0.542 & $0.033^{\mathrm{s}}$ & 3.182 & 1.100 & 9.203 \\
\hline Serum phosphorus & -1.007 & 0.338 & $0.003^{\mathrm{s}}$ & 0.365 & 0.189 & 0.708 \\
\hline BMI & 0.143 & 0.089 & $0.107^{\mathrm{ns}}$ & 1.154 & 0.970 & 1.373 \\
\hline IHD & 0.920 & 0.526 & $0.080^{\mathrm{ns}}$ & 2.510 & 0.896 & 7.034 \\
\hline Hemoglobin & 0.634 & 0.344 & $0.066^{\mathrm{ns}}$ & 1.885 & 0.960 & 3.702 \\
\hline Serum Ca++ & -0.212 & 0.319 & $0.505^{\mathrm{ns}}$ & 0.809 & 0.433 & 1.510 \\
\hline Serum Na+ & -0.671 & 0.512 & $0.191^{\mathrm{ns}}$ & 0.511 & 0.187 & 1.396 \\
\hline Serum K+ & -0.239 & 0.231 & $0.302^{\mathrm{ns}}$ & 0.787 & 0.500 & 1.239 \\
\hline
\end{tabular}

Table-4 shows predictors of mortality. Patients having serum albumin $<3.0 \mathrm{mg} / \mathrm{dl}$ had 4.584 times significantly $(\mathrm{p}<0.05)$ increase mortality $(95 \%$ CI 2.015 to 10.43). Patients having DM had 3.182 times significantly $(\mathrm{p}<0.05)$ increase mortality $(95 \%$ CI 1.10 to 9.203$)$. Patients having serum phosphorus $\geq 5.5$ $\mathrm{mg} / \mathrm{dl}$ had 0365 times significantly $(\mathrm{p}<0.05)$ increase mortality (95\% CI 0.189 to 0.708 ). Others parameters were not significantly associated with mortality in binary logistic regression analysis.

\section{DISCUSSION}

Regarding the demographic profile, in the current study, among 160 patients (alive and dead), majority $68(42.50 \%$ ) were found in age-group 46-60 years followed by $39(24.38 \%$ ) belonged to $30-45$ years. Almost similar to our results, the mean age at initiation of dialysis (50.05 years) was reported in the study of Hemachandar R [18] and was similar to other Indian data but found lower compared to Western countries (62.7 years in the United States Renal Data System, 2013). The age distribution reported by Lakshminarayana GR et al., [19] also correlate well with our study.

The present study also revealed that out of 160 patients, $106(66.25 \%)$ were male and $54(33.75 \%)$ were female in both alive and dead groups. In accordance with our findings, males outnumbered females among those on MHD with M: F ratio of $\sim 2: 1$ pattern consistent with DOPPS and Indian studies in terms of age and sex ratios by Swarnalatha et al., and Chandrashekar et al., [20]. Moreover, majority of the patients were above 40 years (age $49.74 \pm 14.55$ ) and males outnumbered females in a ratio of $3: 1$. The majority of hemodialysis patients in a study were men, congruent with studies in Europe. It has been suggested that men with glomerular disease may have worse prognosis, but there is no conclusive evidence that sex is a determining factor in CKD progression demonstrated by Kjellstrand, C. M [21] A prospective study of 127 ESRD patients initiated on HD was done. The study included 101 males and 26 females, with a mean age of $50.05 \pm 13.80$ years which strongly correlates with our study.
Three fourth $(76.23 \%)$ patients were dependant in alive, $24(63.16 \%)$ in dead and $117(73.13 \%)$ in total. More than one third $(34.43 \%)$ patients were upper middle in alive $17(44.74 \%)$ in dead and $59(36.88 \%)$ in total. Almost two third (61.48\%) patients come in urban area in alive $18(47.37 \%$ ) in dead and 93(58.13\%) in total. Patients initiated on HD in rural area often present late with poor predialysis care leading to high morbidity.

In this study, the co-morbidities found were Diabetes mellitus, Hypertension, Ischaemic heart disease, Hepatitis B virus infection and Hepatitis C virus Infection. Among these, Diabetes mellitus were found $50(40.98)$ in alive and 24(63.16\%) in dead. Hypertension 111(90.98\%) were found in alive and $37(97.37 \%$ ) were in dead. Ischaemic heart disease were $44(36.07 \%)$ in alive and $22(57.89 \%)$ in dead. HBV infection $19(15.57 \%)$ in alive and $06(15.79 \%)$ in dead. $\mathrm{HCV}$ infection $21(17.21 \%$ ) in alive and $03(7.89 \%)$ in dead. Hypertension (HTN) was the most common comorbidity $(96.8 \%)$, followed by left ventricular hypertrophy $(\mathrm{LVH})(80.6 \%)$, coronary artery disease (CAD) $(52.3 \%)$, tuberculosis (11.6\%), chronic liver disease $(4.3 \%)$ and malignancies in $2.2 \%$ of patients, whereas the presence of HTN alone did not affect mortality statistically $(p=0.62)$ reported by Lakshminarayana et al., [19].

Comparison of co-morbidities between alive and dead population, it was observed that more than one third (40.98\%) patients had DM in Alive, 24(63.16\%) in dead and 74(46.25\%) in total. Majority (90.98\%) patients had HTN in Alive, 37(97.37\%) in dead and $148(92.50 \%)$ in total. More than one third $(36.07 \%)$ patients had IHD in Alive, 22(57.89\%) in dead and $66(41.25 \%)$ in total, $19(15.57 \%)$ patients had HBV in Alive, 6(15.79\%) in dead and $25(15.625 \%)$ in total, $21(17.21 \%)$ patients had HCV in Alive, $3(7.89 \%)$ in dead and $24(15.00 \%)$ in total. The difference of DM and IHD were statistically significant $(p<0.05)$ between two groups in our study. Presence of HTN did not affect mortality statistically in our study also $(\mathrm{p}=0.192)$. 
Mamunur Rashid et al; Sch J App Med Sci, Feb, 2021; 9(2): 217-222

Comparing investigation profile in relation to patient outcome, the mean hemoglobin was $9.56 \pm 1.09$ in alive and $9.03 \pm 1.22$ in dead. The mean serum $\mathrm{Ca}++$ was $9.32 \pm 0.82$ in alive and $9.71 \pm 1.05$ in dead. The mean serum phosphorus was $5.05 \pm 1.56$ in alive and $6.50 \pm 1.70$ in dead. The mean serum albumin was $3.56 \pm 0.41$ in alive and $3.05 \pm 0.03$ in dead. The difference of hemoglobin, serum $\mathrm{Ca}++$, serum phosphorus and serum albumin were statistically significant $(\mathrm{p}<0.05)$ between two groups. Serum $\mathrm{Na}+$ was $140.87 \pm 37.77 \mathrm{SD}$ in alive and $138.61 \pm 2.67 \mathrm{SD}$, Serum K+ was 4.75 $\pm 1.06 \mathrm{SD}$ in alive and 4.8 $\pm 0.69 \mathrm{SD}$. The mean hemoglobin in the cohort of Hemachandar presentation $(6.8 \mathrm{~g} / \mathrm{dL})$ was very low compared to 7.7 $\mathrm{mg} / \mathrm{dL}$ in a study by Swarnalatha et al., [20] as well as the mean hemoglobin estimated in our study. In the study of Prabha and Prasad the mean hemoglobin values was $6.67 \mathrm{~g} / \mathrm{dl}$, which were much lower than the recommendations made by kidney diseases improving global outcome (KDIGO), and anemia was not found to be an independent predictor of mortality. This can be attributed to malnutrition, poor compliance with drugs, and insufficient doses of iron and erythropoietin.

Binary logistic regression analysis to identify predictors of mortality showed patients having Serum albumin $<3.0 \mathrm{mg} / \mathrm{dl}$ had 4.584 times significantly $(\mathrm{p}<0.05)$ increase mortality (95\% CI 2.015 to 10.43 ). Patients having DM had 3.182 times significantly $(\mathrm{p}<0.05)$ increase mortality (95\% CI 1.10 to 9.203). Patients having serum phosphorus $\geq 5.5 \mathrm{mg} / \mathrm{dl}$ had 0365 times significantly $(\mathrm{p}<0.05)$ increase mortality $(95 \% \mathrm{CI}$ 0.189 to 0.708 ). Others parameters were not significantly associated with mortality in binary logistic regression analysis.

\section{CONCLUSION}

From our study we can say that, mortality in patients on maintenance hemodialysis was disproportionately high. The most common causes of death were sepsis and IHD. Diabetes mellitus, low serum albumin and high serum phosphorus were found to be independent predictors of mortality. Higher serum albumin \& low serum phosphorus level conferred a survival advantage.

\section{REFERENCE}

1. Alam KS, Huda MN, Rashid HU, Saha M. Prevalence of diabetes mellitus, hypertension, proteinuria and association of these risk factors with estimated glomerular filtration rate (eGFR) in adult disadvantaged population. Bangladesh Renal J., 2010; 29(1):1-6.

2. Faroque MO, Rashid HU, Rahman MH, Alam MR, Islam S. Prevalence of diabetes mellitus, hypertension and proteinuria in a rural area of Bangladesh. Bangladesh Renal J. 2010;29(1):7-11.
3. Hadiuzzaman KB, Rahman $\mathrm{MH}$, Alam MR, Munirunnessa FM, Shah AK, Rashid HU. Prevalence of diabetes mellitus and hypertension in health service providers. Bangladesh Renal J. 2010;29(1):12-5.

4. Rashid HU. Kidney Foundation Year Book. 2012;9:28-31.

5. US Renal Data System: USRDS 2004 Annual Data Report: Atlas of End-Stage Renal Disease in the United States, Bethesda, National Institutes of Health, National Institute of Diabetes and Digestive and Kidney Diseases, 2004.

6. Goldwasser P, Mittman N, Antignani A, Burrell D, Michel MA, Collier J, Avram MM. Predictors of mortality in HD patients. J Am Soc Nephrol. 1993;3:1613-1622.

7. Avram MM, Mittman N, Bonomini L, Chattopadhyay J, Fein P. Markers for survival in dialysis: A seven-year prospective study. J Kidney Dis. 1995;26:209-219.

8. Leavey SF, Strawderman RL, Jones CA, Port FK, Held PJ. Simple nutritional indicators as independent predictors of mortality in HD patients. Am J Kidney Dis. 1998;31:997-1006.

9. Fernandez-Reyes MJ, Alvarez-Ude F, Sanchez R, Mon C, Iglesias P, Diez JJ, Vazquez A. Inflammation and malnutrition as predictors of mortality in patients on HD. J Nephrol. 2002;15:136-143.

10. Cooper BA, Penne EL, Bartlett LH, Pollock CA: Protein malnutrition and hypoalbuminemia as predictors of vascular events and mortality in ESRD. Am J Kidney Dis. 2004;43:61-66.

11. Herzog CA, Li S, Weinhandl ED, Strief JW, Collins AJ, Gilbertson DT. Survival of dialysis patients after cardiac arrest and the impact of implantable cardioverter defibrillators. Kidney Int. 2005;68:818-825.

12. Pisoni RL, Bragg-Gresham JL, Young EW, Akizawa T, Asano Y, Locatelli F, Bommer J, Cruz JM, Kerr PG, Mendelssohn DC, Held PJ, Port FK. Anemia management and outcomes from 12 countries in the dialysis outcomes and practice patterns study (DOPPS). Am J Kidney Dis. 2004;44:94-111.

13. Ma JZ, Ebben J, Xia H, Collins AJ. Hematocrit level and associated mortality in HD patients. J Am Soc Nephrol. 1999;10:610-619.

14. Goodkin DA, Bragg-Gresham JL, Koenig KG, Wolfe RA, Akiba T, Andreucci VE, Saito A, Rayner HC, Kurokawa K, Port FK, Held PJ, Young EW. Association of comorbid conditions and mortality in HD patients in Europe, Japan, and the United States: The Dialysis Outcomes and Practice Patterns Study (DOPPS). J Am Soc Nephrol. 2003;14:3270-3277.

15. Block GA, Klassen PS, Lazarus JM, Ofsthun N, Lowrie EG, Chertow GM. Mineral metabolism, 
mortality, and morbidity in maintenance HD. J Am Soc Nephrol. 2004;15:2208-2218.

16. Kalantar-Zadeh K, Kuwae N, Regidor DL, Kovesdy CP, Kilpatrick RD, Shinaberger CS, McAllister CJ, Budoff MJ, Salusky IB, Kopple JD. Survival predictability of time-varying indicators of bone disease in maintenance hemodialysis patients. Kidney Int. 2006;70:771-780.

17. Young EW, Albert JM, Satayathum S, Goodkin DA, Pisoni RL, Akiba T, Akizawa T, Kurokawa K, Bommer J, Piera L, Port FK. Predictors and consequences of altered mineral metabolism: The Dialysis Outcomes and Practice Patterns Study. Kidney Int. 2005;67:1179-1187.

18. Hemachandar R. Practice pattern of hemodialysis among end-stage renal disease patients in Rural South India: A single-center experience. Saudi Journal of Kidney Diseases and Transplantation, 2017;28(5):1150.
19. Lakshminarayana GR, Sheetal LG, Mathew A, Rajesh R, Kurian G, Unni VN. Hemodialysis outcomes and practice patterns in end-stage renal disease: Experience from a Tertiary Care Hospital in Kerala. Indian journal of nephrology. 2017 Jan;27(1):51-57

20. Swarnalatha G, Ram R, Prasad N, Dakshinamurty $\mathrm{KV}$. End- stage renal disease patients on hemodialysis: A study from a tertiary care center in a developing country. Hemodialysis International. $2011 \mathrm{Jul} ; 15(3): 312-9$.

21. Kjellstrand CM, Blagg CR, Twardowski ZJ, Bower J. Blood access and daily hemodialysis: Clinical experience and review of the literature. ASAIO journal. 2003 Nov 1;49(6):645-9. 